
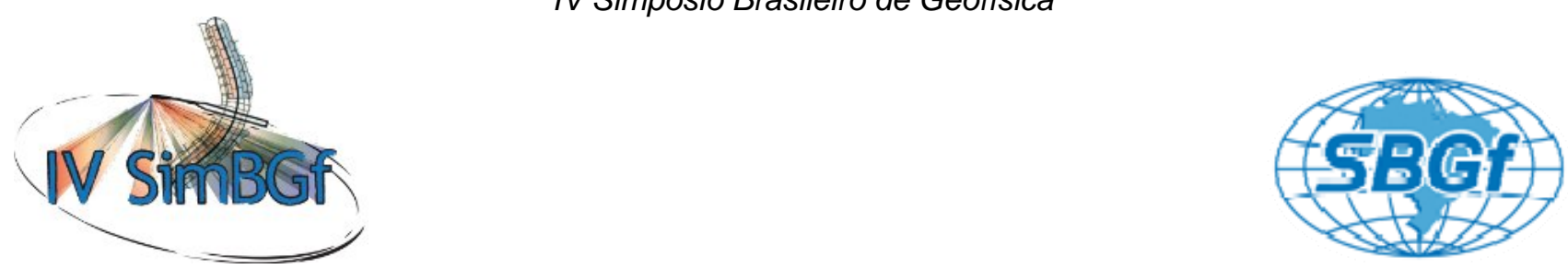

\title{
Relocation of seismic hypocenter and tectonic stresses determination on southern Peru Altiplano Plateau
}

Nathalia Hertz, Ivan Zevallos (Unipampa, RS, ivanzev@gmail.com)

Copyright 2010, SBGf - Sociedade Brasileira de Geofísica

Este texto foi preparado para a apresentação no IV Simpósio Brasileiro de Geofísica Brasília, 14 a 17 de novembro de 2010. Seu conteúdo foi revisado pelo Comitê Técnico do IV SimBGf, mas não necessariamente representa a opinião da SBGf ou de seus associados. É proibida a reprodução total ou parcial deste material para propósitos comerciais sem prévia autorização da SBGf.

\section{Abstract}

An mb 6.1 earthquake was relocated, because it may be useful for tectonic stresses determination, depending on depth of foci. Precise methods of depth determination using $\mathrm{sP}$ phases gives us a $82.6 \mathrm{~km}$ depth for hypocenter; so it is into the continental lithosphere. Neotectonic state of deviatoric stress in a high plateau zone (southern Peru) was inferred from analysis of focal mechanisms. Relative tensor of stress found by inversion of slip planes shows a vertical major main stress, which can be explained by gravity potential effect.

\section{Introduction}

Southern Peru Altiplano plateau is a low level seismic zone; more of the earthquakes registered in that zone are from Wadatti-Benioff zone, so very few crustal earthquakes are available for deviatoric stresses studies.

The earthquake of 2008/07/08 because its magnitude (6.1) would be an important source of information about tectonic regime in that region. However, seismological entities found different foci depth (ISC). So, first than all its necessary a more precise foci depth determination.

Phases $\mathrm{sP}$ and $\mathrm{pP}$ give us a good control of depth of seismic foci. Ploting sP-P step-outs we can see this is in the range of 4.45 seconds, so our hypocenter is less than $100 \mathrm{Km}$ depth. Then, a focal mechanism solution was reached using focmec software and it gave us a pair of nodal planes. Joining to another focal mechanisms from previous studies permits a relative tensor determination by inversion of slip planes.

\section{Geotectonics}

Southern Peru Altiplano it is one of the largest plateaus of the world. The mean altitude of the Altiplano is $3800 \mathrm{~m}$ higth and it constitutes a great mass charge for lithosphere, bending the plate and creating a bulge in the eastern sub-andean zone. Most general structural features are of type normal fault, in highlands, but thrust fault or strike slip faults in the forearc region.

\section{Hypocenter depth}

The $\mathrm{sP}$ and $\mathrm{pP}$ phases provides us a more precise depth determination of the hypocenter because they are stable in concern to there normal move out. We have analized seismograms of seismic stations between $29,7^{\circ}$ to $89,06^{\circ}$ of epicentral distance (fig. 1)

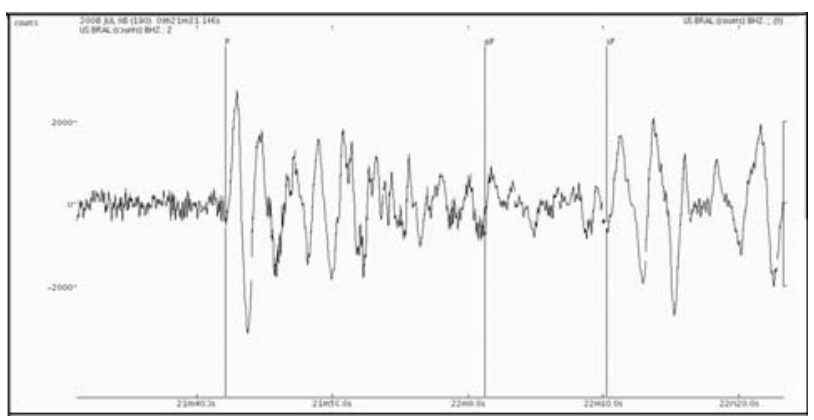

Figure1: seismogram showing $P, p P$ and $s P$ phases. It is known that $p P$ Phase it is not clear for earthquakes of western south America.

We have used a travel time table for $\mathrm{sP}$ phases, at same time checking delay time SP-P with SeisGram software(fig. 2), and by using average mean we have conluded that the best fit depth is $82.6 \mathrm{~km}$. (fig. 3).

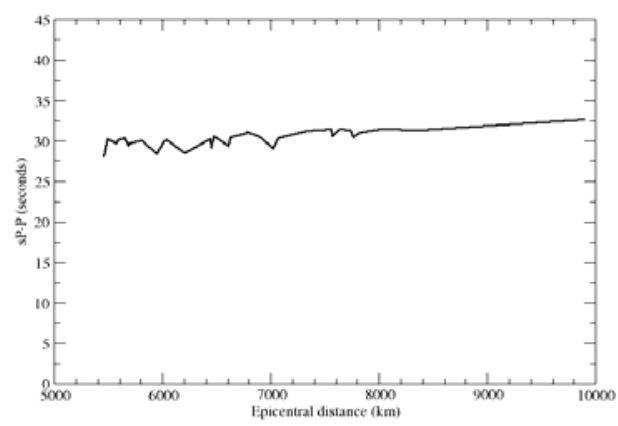

Figure 2: sP-P step-out versus epicentral distance. 


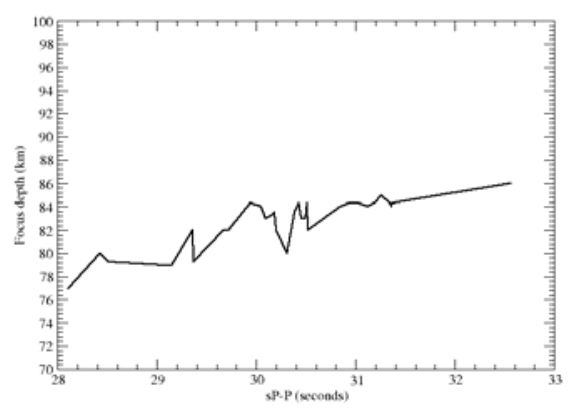

Figure 3: Focus depth versus SP-P step-out.

\section{Focal mechanism}

The $\mathrm{P}$ wave fist arrivals plotting technique was used to determine focal mechanism of 2008/07/08 earthquake (focmec, Snoke, 2003). Beach ball (Fig. 4) related to compressional and tensional areas indicates a near normal faults regime.

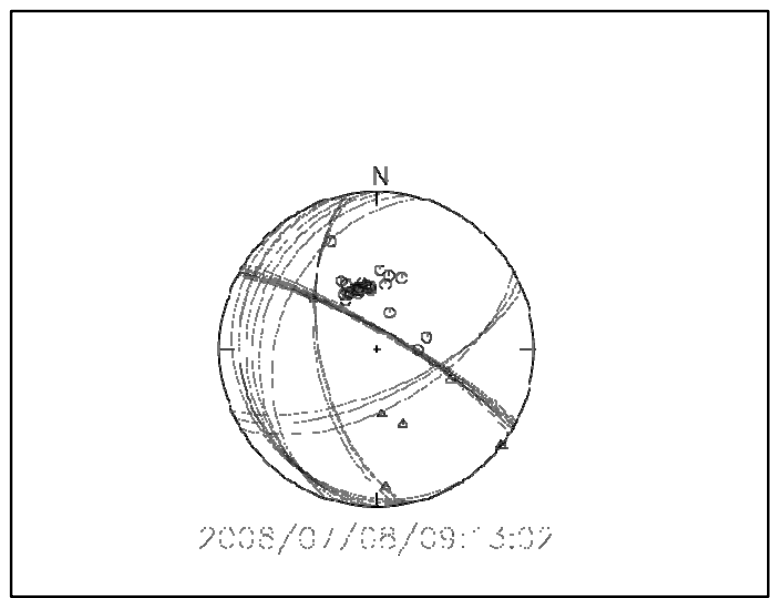

Figure 4: focal mechanism solution for Yura earthquake.

\section{Neotectonic stress regime}

We can know present day stress regime in the Altiplano by inversion of slip planes from focal mechanisms (fig. 5).

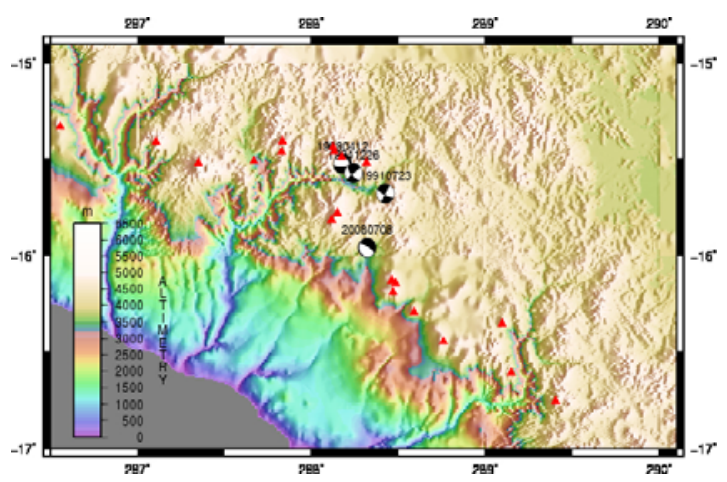

Figure 5: map with earthquakes locations; Altiplano plateau (southern Peru).

We can find the direction of main stresses by mean of a global search algorithm. So, $\sigma_{1}, \sigma_{2}$ and $\sigma_{3}$ have to satisfy the position of nodal planes in focal mechanisms solutions. The Michael's (1984) program for stress inversion gives result showed in figure 6 .

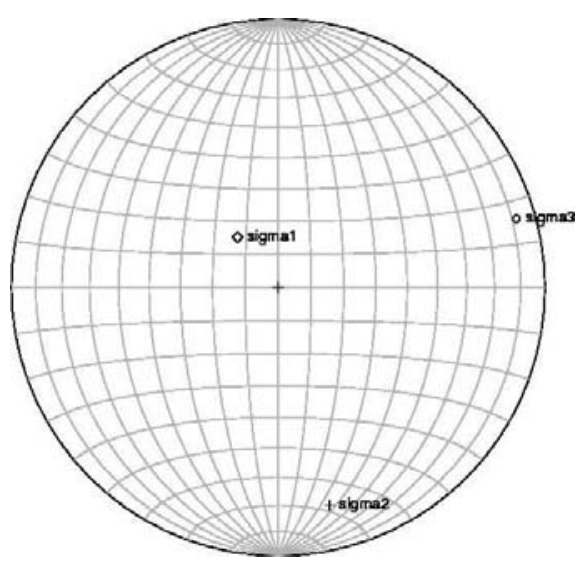

Figure 6: Stereonet showing result for deviatoric stress tensor inversion. 


\section{Conclusions}

Main stresses found are in well correlation with GPE inferences; $\sigma_{1}$ is near vertical, configuring a normal faults structural regime. The direction of $\sigma_{3}$ follows the direction of widest axis of Altiplano, indicating that Andes are expanding in this direction and creating a push force on sub-andean zones.

\section{Bibliographic references}

Michael, A.J. (1984), Determination of stress from slip data: faults and folds, JGR, v. 89, 11,517-11526.

Snoke, J.A. (2003). FOCMEC: FOcal MEChanism determinations. International Handbook of Earthquake and Engineering Seismology (W.H.K. Lee, H. Kanamori, P.C. Jennings, and C. Kisslinger, Eds.), Academic Press,
San
Diego,
Chapter
85.12

R. Murphy and B. W. Barker: Improved Focal-Depth Determination through Automated Identification of the Seismic Depth Phases $p P$ and $s P$ Bulletin of the Seismological Society of America, Aug 2006; 96: 1213 - 1229.

ISC. http://www.isc.ac.uk/ 